\title{
Treatment of Bonds at the Time of Reorganization
}

\author{
By Arthur S. Dewing \\ Graduate School of Business Administration, Harvard University
}

A DISTINGUISHED jurist remarked, nearly forty years ago, that "it rarely happens in the United States that foreclosures of railway mortgages are anything else than the machinery by which arrangements between creditors and other parties in interest are carried into effect." 1 This apparently revolutionary doctrine represented the acknowledgment by the highest court that the adjustment of the financial misfortunes of a railroad was to be conducted along different lines from the adjustment of the affairs of any other bankrupt business. It was the tacit acknowledgment that a railroad occupied a peculiar and individual position in our economic life and that its financial affairs were affected by its social significance. In effect, it was the extension of the social responsibility of a railroad's operation, -as developed in preceding years ${ }^{2}$ to a railroad's financial affairs. Prophetic of the future was Justice Waite's grasp of the substance behind the form of a railroad reorganization, for since this statement was made the entire current of events in the field of railroads has been such as to amplify and reinforce its truth. Furthermore, the whole course of corporate reorganizations in all fields of industrial activity has followed in the wake

1 Chief Justice Waite, Can. So. Ry. Co. v. Gebhard, 109 U. S. 539 (1883).

${ }^{2}$ Granger cases beginning Munn v. Illinois, 94 U. S. 113 (1877); to Stone v: Wisconsin, 94 U. S. 181. of his theory of railroad reorganization.

The present theory and practice of corporate reorganization has been the result of a slow evolution in which the exigencies of financial necessity have always dominated legal forms. This is clear from its purpose; for reorganization is surgery applied to corporate failure. It is the climax of blasted hopes and thwarted ambitions. As such, it is, even in its happiest light, merely an expedient for making the best out of an unfortunate situation. It necessarily involves a conflict of legal rights, and it is necessarily carried through under the stress of disappointment, ill-temper and personal animosities. It reaches down into the fundamentals of corporate affairs. For this reason, if for no other, it is at once the most intricate and at the same time the most fascinating topic of corporation finance.

\section{Factors Determining the Status of Bonds at Reorganization}

The fundamental character of the general subject of reorganization is shown by the treatment of bonds. For, in the end, the real and abiding security of a bond issue is its probable treatment at the time of reorganization. All else is superfluous. The mortgage securing the New York and Erie Railroad $4 \mathrm{~s}$ of 1947 is the simplest and crudest railroad mortgage now in force. No corporation lawyer of the present would think of employing anything like it to secure a contemporary issue 
of bonds; yet, probably no corporation bonds are more secure than those issued under this old mortgage. The bonds are a first lien, of over seventy years' standing, on the main trunk line, representing the most important section of the shortest route between New York harbor and Chicago. They have withstood three separate reorganizations of the Erie system.

Five fundamental and important sets of conditions determine the status of any bond issue at the time of the reorganization of the corporation which is liable for the issue. The first two are concerned with the nature of the corporation, without reference to the bond issues involved in the reorganization. Two other sets of conditions are concerned with the economic and strategic position of the specific issue of bonds, in relation to the other obligations and liabilities dealt with in the reorganization. The fifth set of determining conditions is legal; superficially, these are of paramount importance; actually, they are insignificant compared with the others. Before discussing the treatment of any bond issue in particular, it is necessary to understand the bearing of these underlying factors.

\section{Public Attitude Toward Bankrupt Corporations.}

The first set of conditions is concerned with the public attitude toward the necessity and social importance of the business conducted by the bankrupt corporation. At the one end of a series is the privately owned water company, the business of which is so essential to the life of the community which it serves that public officials exercise a strict supervision over the conduct of its business. Of similar inestimable economic importance to the nation are the great railways which make our present industrial organization possible. At the other end of the series are the small, locally owned manufacturing businesses engaged in the production of unimportant luxuries, of which the supply is always ample. Businesses of the former type are so interwoven into our modern mode of living that we designate them collectively by the term "public utilities." As the industrial order changes, businesses which at one time were not of great social significance become so, and the courts, sanctioned by social opinion, invest them with the privileges, restrictions and limitations that belong to public service corporations. The attitude of the public, as crystallized in judicial precedents and statutory law, toward the public character of a business has much to do with the treatment of the corporation's bonds at the time of reorganization. If the business of a bankrupt corporation is invested with a public character, the courts may permit a great variety of past and present debts to supersede all the bonds, even the underlying first mortgage, provided such a course is necessary in order to keep the public service enterprise in actual operation; whereas, a bankrupt business not invested with a public character will be liquidated by the courts for the benefit of the creditors, and no general creditor can acquire a priority of claim sufficiently strong to emasculate the security of the mortgage bondholders. In the one case, public convenience or necessity may supersede all the contractual priorities of a mortgage bond; in the other case, 
the claims of the various creditors, including the bondholders, to the bankrupt's property follow logically the order of their lien on the corporate estate.

\section{Character of Business Conducted by the Corporation}

The second set of conditions are concerned with the specific character of the business conducted by the bankrupt corporation - the kind of market it supplies, the merchantability of its assets, the rapidity with which its capital is "turned over" and its natural capacity for borrowing capital. There is one type of business requiring a large amount of fixed capital, of which a power dam is an illustration, which has no current quick assets that can be sold for the benefit of creditors. It requires little or no working capital and, therefore, once it is in operation, it requires no loans from the banks. It supplies a relatively stable market. The services it sells cannot be "trademarked" and little business skill is required for its administration.

At the other extreme is the type of business which requires little fixed capital-as a tannery-where the current assets constitute about all there is to the value of the corporation's property. The capital is "turned over" readily; the volume of purchases and sales fluctuates rapidly, so that large amounts of bank credit must be available at certain times. It produces a commodity for a highly competitive market and great skill is required for the administration of the business.

In the reorganization of the former type of business, general as well as underlying bonds may be left undisturbed, because the reorganized cor- poration will have an assured and relatively constant earning power, and no need would arise for securing bank loans to carry, temporarily, an unusually large volume of business. In the reorganization of the second type, the old bonds must be scaled down to the lowest possible point, and in reorganization plans of markedly good technique all bonds of the bankrupt corporation are converted into stock. The plan must safeguard, above all else, the general borrowing credit of the reorganized corporation, and preserve the organization, the "good will" and the trade standing of the business. A bond, even a mortgage bond, of such a business is an empty symbol unless these intangible elements are maintained.

\section{Economic Position of Bond Issues}

The third set of conditions pertain to the earning capacity of the particular property which secures one bond issue in contrast to another bond issue of the same bankrupt corporation. In the reorganization of a large railway system, a large local utility on an industrial "trust" of hybrid origin, there are usually several separate issues of bonds. One issue is secured by a mortgage on one piece of property; another issue by a mortgage on an entirely different piece of property; and the two pieces of property have probably contributed differently to the earning capacity of the bankrupt corporation. Obviously, the bonds secured by the more lucrative property must be treated more liberally than those secured by property having a less inherent earning capacity. Obviously, no bondholders can be asked, under any circumstances, to accept new securities in a reorganized com- 
pany which yields less income than the distinguishable earning capacity of the property securing the bonds; and, equally self-evident, bondholders whose only security is property having little or no independent earning capacity may be justly asked to endure any sacrifice in income short of the complete extinction of their investment.

\section{Strategic Position of a Bond Issue}

The fourth set of conditions have to do, again, with the property securing an issue of bonds-the strategic significance, rather than the explicit earning capacity, of the property. For it is true that in any complex financial structure the property securing one bond issue is more essential to the operation of the business as a whole than the property securing another. Obviously, the former issue must be treated with conspicuously greater liberality than the latter. This distinction is of great importance in adjusting the relative interests of different small, and separately secured bond issues in every complex reorganization, but it is especially important in the reorganizations of large railway systems. For, obviously, the holders of bonds secured by a mortgage on the main trunk stem of a railway system must be treated with the utmost liberality. They must be treated, in actual practice, with much greater liberality than the holders of bonds secured by a mortgage on a branch line, the traffic on which is important but not absolutely essential to the integrity of the reorganized property.

\section{Legal Conditions}

The fifth set of conditions to be considered are legal. Except in rare cases, ${ }^{3}$ all bonds are issued under a covenant or indenture which specifies, explicitly, the rights of the bondholders in case of default. Often, however, federal and state statutes or judicial precedents have altered the signifcance and the strength of the legal privileges accorded the bondholders in their contract with the corporation, and these privileges, so far as they are binding, have a direct bearing on the claims of the bondholders to the assets of the corporation. Then, too, the general machinery prescribed by judicial procedure.tempers the relative standing of bond issues. If the reorganization follows a foreclosure of one of the bond issues and a judicial sale of the assets of the corporation, severe pressure can be exerted on all the junior bondholders. In all respects, except actual command, 4 court can impose a reorganization plan

${ }^{3}$ Like certain old debentures of the New York, New Haven and Hartford, and the Boston and Maine Railroads.

"The court, by approving of the conditions of the judicial sale, may indirectly force the dissenting minority to accept the plan of reorganization approved by the assent of an overwhelming majority. But the court cannot directly force a security holder to accept a plan. "It is clear that the courts cannot directly or indirectly rewrite this reorganization agreement."-Guar. T. v. Inter. Steam Pump Co., 231 Fed. 595 (1916). This was tried in one notable case, but the United States Circuit Court of Appeals (Supreme Court Justice Brewer rendering the opinion) declared against any such use of the court's power, on the ground that "there is no wide discretion vested in the chancellor which permits him to disturb contract rights -the rights of property. . . . It is not for the court to assume the power to compel because it believes it wise and good business. . . . Every man in this country decides questions in respect to his own property for himself."Merchants' Loan and Trust Co. v. Chicago Rys. Co., 158 Fed. 923 (1907). 
upon recalcitrant bondholders. On the other hand, if no foreclosure sale is ordered by the court, and the plan of reorganization is carried out by persuasion only - without judicial pressure-then all the bondholders must be treated with great leniency. In some rare cases, there are special state statutes which affect the general priority of bondholders ${ }^{5}$ and, in other instances, the mental slant of the federal and state judges of the geographical region in which the reorganization occurs may affect the attitude of the court toward the sacredness of mortgage contracts. Yet, when all is said, the legal conditions of the reorganization are, on the whole, important, chiefly, as determining the form of the reorganization and the extreme limits that a reorganization committee can go in demanding sacrifices from bondholders; whereas, economic sanctions determine the substance or structure of the reorganization plan and the particular distribution of the sacrifices demanded of the various classes of security holders.

\section{“REORGaNization IMPERATIVEs"}

These considerations apply to concrete cases of the treatment of particular bond issues in specific reorganizations. They are, however, circumscribed and limited in their application to two considerations which are paramount in every reorganization. The fixed charges of the reorganized company must be reduced so as to be well

${ }^{5}$ In the recent reorganization of the Jackson Light \& Traction Company of Mississippi, the first mortgage bondholders' committee found that an old state statute seemed to give the resident merchandise creditors a priority over the first mortgage bondholders. within the earning power of the corporation and the reorganized corporation must be supplied with new money. The relative importance of these two considerations - one might almost call them reorganization imperativesvaries with the nature of the business conducted by the bankrupt corporation and the seriousness of the failure. But that they are of paramount importance is tacitly acknowledged by every practical business man who pretends to prescribe for a sick corporation, and explicitly stated by every writer on reorganization procedure. Possibly the most lasting contribution of the late J. Pierpont Morgan to the orderly development of American finance was his insistence that in the great railroad reorganizations, of which he was the dominating factor, these two principles should be strictly observed. And the railroad reorganizations following the panic of 1893 are to be contrasted with those that preceded it by a strict observance of these imperatives, notwithstanding the losses this involved. ${ }^{6}$

The detailed working out of these two imperatives gives rise to the problems and expedients encountered in every individual corporate reorganization. Let us consider, first, the reduction of fixed charges to within the reasonable limits of the earning capacity of the corporation. This is the point which most concerns the treatment of bonds.

- For brief study of the historical development of the theory of railroad reorganization, see Dewing, A. S.-The Theory of Railroad Reorganizations, 8 American Economic Review, 774 (Dec. 1918). 


\section{Reduction of Fixed Charges}

\section{Equipment Obligations}

If the corporation to be reorganized is a railroad, any outstanding equipment trust obligations must be continued either according to their original tenor or else paid off in money. There is no other alternative. This is especially true if they were issued under the so-called Philadelphia plan, by which the title to the equipment does not pass to the road until the last installment of the trust is paid. Unless these obligations are paid, or at least continued, the owners can withdraw the locomotives and cars from the jurisdiction of the receiver and the railroad is deprived of its rolling stock and hence its ability to carry on its business. As a result of the observation of this principle, which brooks no exception, equipment obligations have a better investment standing than any other class of investment securities. ${ }^{7}$

\section{Receiver's Certificates}

The other type of bonds that receives special consideration in every type of reorganization are the receivers' certificates. These are issued either

7 The present writer does not know of a single case, throughout the whole range of American finance, wherein the holders of equipment obligations have been forced to endure a permanent loss. There are several instancesDenver and Rio Grande reorganization of 1886 and the Norfolk and Western reorganization of 1896-in which the holders were forced to refund their equipment obligations, but in the end they recovered the principal and interest. In two recent cases-Detroit, Toledo and Ironton, and Buffalo and Susquehanna Railway-the equipment under the obligations was withdrawn from the railroad and sold. But the prices realized were ample to satisfy the outstanding obligations. to pay off the "six months" claims existing at the time of the receivership or else to secure the money to enable the receiver to meet absolutely necessary expenses when the current income is insufficient. Under ordinary circumstances, a reorganization plan must provide sufficient money to pay off, at par, these receiver's certificates, else the court will not permit the plan to be carried out. This applies to all types of reorganizations-railroad, public utilities and industrials-although it should be noted in passing that our federal courts show far greater willingness to permit their receivers to issue certificates of indebtedness that take priority over mortgage bonds in railroad receiverships than in industrial receiverships. Obviously, this attitude is based on the presumption that the right of the public users of a railroad to have good service takes priority over even the contractual rights of mortgage creditors. The principle of the inviolability of the claims of the holders of receivers' certificates has received some severe shocks of late, when the severity of several small railway failures has compelled even the holders of these certificates to undergo radical sacrifices. It is also interesting to note that the great legal strength of these obligations of the courts has proved less of a protection to investors than the mere business expediency upon which equipment obligations rest. ${ }^{8}$

8 Perhaps the most instructive of these severe failures is that of the Atlanta, Birmingham and Atlantic Railroad. At no time during the reorganization was there any question but that the equipment obligations would remain undisturbed by a reorganization. The interest and installments of principal were regularly paid. But in the first plan of reorganization (March, 


\section{Special Bond Issues}

With the exceptions of equipment securities and receivers' certificates, all the bonds dealt with in any reorganization are the specific obligations of the financially embarrassed corporation itself. Their treatment is, therefore, a matter of comparative values. When it comes to lay down broad principles governing the treatment of special bond issues, one is confronted with hopeless confusion unless the general distinctions suggested in the opening paragraphs of this article are carried in mind. Of these, the one which is applied relentlessly, in formulating the reorganization plan of every bankrupt corporation, is the purely business principle that the holders of bond issues shall undergo sacrifices if the earnings of the corporation before the failure were insufficient to meet their fixed interest charges. This simple principle is seldom violated. It takes precedence over all others. For it is obvious that if bonds were allowed to remain undisturbed, when past experience had shown that the reorganized company could not earn the charges upon them, the corporation would immediately fail again. Legal and equable rights of every description are dominated by the motive of giving the reorganized company at least a reasonable chance of surviving the immediate repetition of failure.

\section{Small Underlying Issues}

Among the various classes of bonds least likely to be in any way affected

1914) it was proposed to give the holders of receivers' certificates only 60 per cent in cash. And in the final plan of reorganization the holders of the receivers' certificates were forced to accept income bonds of subordinate and meagre value. by the reorganization, or called upon to make any real sacrifice, are the small, underlying issues. If they represent first mortgages on essential parts of the railway, the lighting system or the industrial plant, their position is probably impregnable, provided the net earnings of the entire corporation exceeded their fixed charges.

Sometimes, however, these underlying issues are refunded into large blanket mortgages, even though their holders are asked to make neither a real nor an apparent sacrifice. This usually occurs when the failure is unusually severe, and the reorganization plan proposes to simplify the entire financial structure of the corporation. Yet it should be noted in passing that in the reorganization of small corporations, the failure of which was so severe as to practically exhaust their apparent assets, it may be necessary for even the underlying bondholders to undergo a very substantial sacrifice. In a few cases of small railroads, the value of these first mortgage bonds has been utterly extinguished by the superposition of receivers' certificates above them, and the final sale of the corporate assets for even less than the receivers' certificates. $^{9}$

\footnotetext{
${ }^{9}$ The difficulty of forming any generalizations concerning the treatment of even prior lien bonds at the time of reorganization has led the writer of the present article to attempt to classify railroad failures and reorganizations with this very matter in view. It would appear that there are three types of railroad failures and resulting reorganizations.

Class I. This embraces serious, thoroughgoing failures of large railway systems. The causes are deep-seated and long-continued; the system has been over-extended; it has been under-maintained; it has not, nor is likely to have, an inherent earning capacity commensurate with its invested capital. Reorganiza-
} 
Junior Mortgage Bonds and Debentures.-Junior to the layers of underlying bond issues there are usually large issues of bonds, either mortgage or debenture, which represent the general obligations of the corporation. In fact, quite generally among industrials and also in the cases of railroads and public utilities which have been reorganized before, the senior issue of these general bonds represents the first funded lien of the corporations, as there are no prior lien underlying issues. The manner of treating these general bond issues is determined entirely by the past earnings of the corporation. If these were fully ample to meet the interest charges, then the issue is treated like one of the underlying mortgages. It is either allowed to remain undisturbed or else is refunded into a new issue of bonds with no loss or sacrifice to the holders.

tions of this type are as thoroughgoing as the failures which preceded them. Usually all the bonds of every description, including the underlying divisional and main line prior liens, are refunded into one, or, at the most, into two great consolidated issues. Generally the old general, refunding or debenture junior liens are refunded into preferred stock and rarely income bonds. Illustrative of this type are the Wabash reorganization of 1888, the Norfolk and Western reorganization of 1896 and, conspicuously, the recent Pere Marquette reorganization of 1907.

Class II. This embraces less serious failures of large railway systems. The causes are temporary, easily diagnosed and easily remedied. Although the earnings of the system are depressed, the best judgment indicates that the system contains an inherent earning capacity commensurate with its capitalization. Reorganizations of this type seldom penetrate beneath the superficial layers of the financial plan. The underlying and first general mortgage bonds are not disturbed. Quite frequently the only important result of the reorganization is the refunding of the uppermost layer of fixed charge
A serious question arises when it is quite doubtful, after adequate depreciation or maintenance charges are allowed, that the earnings of the corporation were adequate to meet the interest charges on the issue. Clearly, to allow the bonds of such an issue to remain undisturbed would be to jeopardize the solvency of the reorganized company. The charges upon them must be reduced or even entirely extinguished.

Until the reorganizations of the middle nineties, it was the custom to fund the coupons for the succeeding few years on the bonds upon which charges had not been earned. This gave the corporation a temporary rest from burdensome capital charges. But this was, at best, only a palliative and secured to the reorganized company no permanent relief. A much sounder practice is followed at the present time. Instead of seeking merely a temporary

obligations into preferred stock. Excellent illustrations of this type are the recent reorganizations of Chicago, Rock Island and Pacific Railway, and of the Missouri Pacific Railway, both in 1917.

Class III. This embraces the failures of small, local, unimportant and often unfinished railroads. As the securities are closely held and the fortunes are not of much public concern, the public admission of failure is usually postponed until the last ray of hope has vanished. Consequently, when the failure actually does come, it lays bare a very serious situation. In consequence, the reorganization of these little roads almost invariably involves the elimination of all security holders junior to the prior lien bonds. It involves, too, the refunding of these bonds into preferred and common stock, and usually an assessment in addition. In fact, instances are by no means rare in which the prior lien bonds are extinguished by the failure of the assets to sell for enough to pay the receivers' certificates.

For further details concerning this classification see 9 American Economic Association Review, 277 (June 1919). 
"rest" for the corporation, one of four expedients is tried. Each one of these gives to the reorganized company some measure of permanent relief, although it invariably involves a considerable sacrifice on the part of the bondholders.

One method is to refund the old bonds into new long-term bonds of the same principal amount, but with a lower interest rate. A second method is to refund the old bonds into two new securities, one with fixed and the other with contingent charges. ${ }^{10}$ Thus the holder of $\$ 1,000$ par value of the 5 per cent general bond issue of a corporation which had failed to earn the full 5 per cent on the issue before the failure might receive $\$ 500$ par value in new 5 per cent general bonds and $\$ 500$, or even $\$ 700$, in new preferred stock. In this way the obligatory fixed charges would be cut in half, or very much reduced. A third method has been to refund the entire issue into new preferred stock bearing a higher rate of contingent return than the fixed charge on the old bonds. This method is frequently used when the issue is large and it is obvious that considerable amounts of money must be spent on the property of the corporation in the years immediately following the reorganization. It has the very great advantage of insuring the reorganized corporation complete rest from the fixed charge. A fourth method, considerably used

${ }^{10}$ The word "contingent" as applied, in this article, to securities or charges implies that the charges which such securities bear are contingent on the earnings of the corporation. They need not be paid unless the earnings are sufficient, and a lapse in their payment will not precipitate the failure of the corporation. In this sense preferred stock and income bonds are contingent securities, and the dividends and warrants they bear represent contingent charges. in the earlier reorganizations and somewhat revived of late, is to refund the fixed charge bonds into income bonds. And often two separate issues of income bonds are used, so that a portion of the contingent charge carried by the new securities has a priority over the rest. In this way the bondholder, who is forced to forego his fixed income, secures the assurance that at least some of his lost income will be restored to him at the earliest opportunity. ${ }^{11}$

The decision as to which of these methods of dealing with the general bonds shall be adopted rests very largely upon the special circumstances attending each reorganization. If the failure was occasioned by special causes-embezzlement, failure of large creditor, sudden shrinkage of inventory, or even a nation-wide stringency in the money market-probably no very serious sacrifices will be asked of the bondholders. Almost certainly they will not be asked to refund their bonds into income bonds or preferred stock, with the positive assurance that other new fixed-charge bonds will be superimposed ahead of their securities. But this is exactly what will happen if the failure is due to deep-seated and farreaching causes. The justice doled out to the bondholders is purely a matter of expediency.

${ }^{11}$ This was the method pursued in the reorganization of the St. Louis and San Francisco Railroad in 1916. The important use of income bonds-on the whole an obsolete practice-is only one phase of an altogether stupid plan of reorganization. For, historical precedents and business expedients considered, the reorganization plan of the St. Louis and San Francisco Railroad shows the least insight and intelligence of any of the great railway reorganizations of the last decade. 
When it comes to the manner of treating those layers of junior securities upon which the interest charges were not earned, by any subterfuge of accounting, there is now almost complete unanimity of judgment. They are invariably refunded into preferred or common stock. In large railroad and public utility reorganizations they are refunded into preferred stock bearing, ordinarily, non-cumulative dividends equal to, or possibly one per cent higher than, the fixed charges on the old bonds. ${ }^{12}$

In industrial reorganizations these junior bond issues, upon which the interest charges were not earned prior to the failure are usually refunded into common stock. In fact one very wholesome characteristic of industrial reorganizations, as a class, is the willingness of reorganizing managers, forced, to be sure, more by necessity than choice, to reduce and, if possible, eliminate, both the contingent as well as the fixed charges. There is a tacit acknowledgment that an industrial enterprise, especially one that must rehabilitate its credit, should bave few direct or indirect liens upon its earnings.

\section{Methods of Procuring New Money}

Less, by far, need be said concerning the treatment of bonds in securing the other purpose of practically every reorganization-the procuring of new money. Although this is often the

\footnotetext{
12 Securities bearing exactly this standing were the First and Refunding Mortgage 4s of the Wabash Railroad, the First and Refunding 5s of the Missouri Pacific Railway, and the Debenture 5 s of the Chicago, Rock Island and Pacific Railway. In the recent reorganizations of these systems each one of these issues was refunded into a new preferred stock.
}

crux of the reorganization-quite generally it is so in an industrial reorganization-yet its burden almost always falls on other interests than the bondholders. In railroad and public service reorganization plans this burden falls on the stockholders who are forced to subscribe new money or suffer the extinction of their equities through the foreclosure of the bonds and the judicial sale of the corporate assets. In industrial reorganizations the burden of supplying new money is often divided among the stockholders and the unsecured creditors-the latter being forced, as well, to fund their obligations into a preferred stock.

But bonds are not always freefrom the necessity of supplying at least some of the money required by the reorganization. If the amount of money required to settle with the various creditors that need it and to rehabilitate the weakened credit of the corporation is more than the reorganization managers believe can be coerced from the stockholders, then they will assess the junior bondholders. It is purely a matter of expediency. If the new money cannot be obtained from the stockholders without running the danger of driving them away, then some of the burden must be passed on to the next higher layer of security holders. This is the junior bondholder. ${ }^{13}$ And

${ }^{23}$ This principle is succinctly stated in an often quoted passage from a circular issued at the time of the second reorganization of the Atchison, Topeka and Santa Fé Railroad. After stating that the amount of money to be raised amounted to $\$ 14,000,000$, the reorganization committee went on to say:

"The stockholders in the ordinary course should provide the whole of this amount . . . but the proportion of the assessment that would be borne by the stockholders could only 
if, in turn, the junior bondholders cannot be counted upon to sacrifice very much to protect their equity, then at least a share of the burden may be passed on up to the senior bondholders. ${ }^{14}$ In some instances the bondholders are placed in the position of guaranteeing the assessments levied on the stockholders, so that if the latter default, the junior bondholders step

be gauged by the amount of assessment that they would be willing to pay in order to protect their rights. This amount is believed to be $\$ 10$ per share, and it is necessary that the second mortgage bondholders shall provide the remaining $\$ 4$ for their own protection." into their position, pay their assessments and take the securities allotted to them. In some industrial reorganizations, too, the debenture bondholders find themselves forced to subscribe sufficient money to pay off certain preferred creditors in order to give themselves a controlling voice in the reorganization. Again, it is a matter of expediency.

14 This was the procedure followed in the reorganization of those small railroads (Class III enumerated in note 9 page 30) which required the foreclosure of the senior mortgage and the total extinction of all junior securities. 